\title{
Resistance of Escherichia coli and Salmonella typhimurium to Carbenicillin
}

\author{
By H. C. NEU AND H. S,WARZ \\ Department of Medicine, College of Physicians and Surgeons, \\ Columbia University, New York, New York 10032, U.S.A. \\ (Accepted for publication 30 June 1969) \\ SUMMARY
}

Carbenicillin, a 9-alpha carboxybenzyl penicillin, is bactericidal only for Escherichia coli strains which are resistant to less than $125 \mu \mathrm{g} . / \mathrm{ml}$. of ampicillin. All E. coli and Salmonella typhimurium strains in which penicillinase is a surface enzyme are resistant to carbenicillin. E. coli and $S$. typhimurium strains in which production of beta-lactamase is episomally mediated are resistant to both ampicillin and carbenicillin. A non-hydrolyzable penicillin (methicillin or dicloxacillin) does not allow carbenicillin to exert its antibacterial effect against resistant strains of $E$. coli, Pseudomonas, Klebsiella or Enterobacter. Carbenicillin shows no synergy with penicillinase-resistant penicillins.

\section{INTRODUCTION}

Carbenicillin is an alpha carboxybenzyl penicillin synthetised from the 6-aminopenicillanic acid nucleus. It differs from ampicillin in that a carboxyl group is substituted for an amino group at the alpha position. The drug is hydrolyzed by $\beta$-lactamases to produce alpha carboxybenzyl penicilloic acid. Since its introduction for the treatment of Pseudomonas and Proteus infections (Brumfitt, Percival \& Leigh, 1967), strains of ampicillin-resistant Escherichia coli which are also sensitive to this drug have been reported (Acred et al. 1967, Bodey \& Terrell, 1968). Previous work from this laboratory on the location of $\beta$-lactamases in $E$. coli (Neu, 1968) suggested that carbenicillin sensitivity was related to the low level of penicillinase production of certain $E$. coli strains.

In the present investigation we have studied carbenicillin resistance in Escherichia coli and Salmonella typhimurium and related it to ampicillin resistance and surface location of penicillinase, whether that enzyme is episomally mediated or not.

Synergism between combinations of penicillins has been reported for ampicillin and penicillinase resistant penicillins such as methicillin and cloxacillin (Sutherland \& Batchelor, I964). We have therefore sought synergism between carbenicillin and the $\beta$-lactamase-insensitive penicillins in a variety of Gram-negative rods.

\section{MATERIALS AND METHODS}

Materials. Carbenicillin was obtained from Beecham Inc. Dicloxacillin and methicillin were obtained from Bristol Laboratories.

Organisms. Escherichia coli, Pseudomonas, Proteus, Klebsiella and Enterobacter strains were obtained from the diagnostic laboratories of the Presbyterian Hospital. 
Salmonellae were a generous gift of Dr Winter of the Beth Israel Salmonella Centre. $E$. coli isolates had been selected on the basis of resistance to $10 \mu \mathrm{g}$. ampicillin discs.

Tube dilution sensitivity tests. A dilution, containing $10^{4}$ organisms, of an overnight trypticase soy broth (BBL) culture of the test organisms was added to tubes containing dilutions of carbenicillin or ampicillin (final vol. $\mathrm{I} \cdot 0 \mathrm{ml}$.) and incubated at $37^{\circ}$ for $\mathrm{I} 8 \mathrm{hr}$. and then observed for growth. Bactericidal levels were obtained by plating clear tubes.

Broth dilution tests for synergy. A checkerboard arrangement of test tubes was used to test the effect of pair antibiotics. Tubes were arranged in five rows of 12 tubes each. Each row contained the same concentration of penicillinase inhibitor (methicillin or dicloxacillin; o, 100, 500, 1000 or $2000 \mu \mathrm{g} . / \mathrm{ml}$.) and successive tubes in an alternate row contained carbenicillin $0,2,4,8,16,32,64,125,250,500,1000$ and $2000 \mu \mathrm{g} . / \mathrm{ml}$. Antibiotics were prepared fresh for each test; inoculation and incubation were as above. The first clear tube was taken as the minimum inhibitory concentration (MIC) for that organism; clear tubes were plated to obtain the bactericidal level.

Carbenicillin assay. A $12 \times 12$ in. glass plate was poured with $450 \mathrm{ml}$. of trypticase soy agar (BBL) seeded with $5 \mathrm{ml}$. of an overnight culture of the Elsworth pseudomonas strain. Wells of $6 \mathrm{~mm}$. were punched in the agar, and $0.06 \mathrm{ml}$. of the test solution placed in the wells. The plate was incubated at $35^{\circ}$ for $\mathrm{I} 8 \mathrm{hr}$. Concentration of carbenicillin was determined using 5, 10, 20 and $40 \mu \mathrm{g}$. carbenicillin standards and measuring diameters in $\mathrm{mm}$. of the zone of growth inhibition.

Procedure for osmotic shock. Stationary-phase organisms were harvested at $16 \mathrm{hr}$ after a $\mathrm{I} \%$ inoculation into Penassay broth (Difco) and washed twice at $2 \mathrm{I}^{\circ}$ with $0.03 \mathrm{M}-\mathrm{NaCl}+0.0 \mathrm{I} \mathrm{M}$ Tris- $\mathrm{HCl}(\mathrm{pH} \mathrm{7.3})$. They were suspended in $0.5 \mathrm{M}$-sucrose + $\mathrm{M}$ Tris- $\mathrm{HCl}(\mathrm{pH} 7.5)$ at $2 \mathrm{I}^{\circ}$ at $10^{10}$ cells $/ \mathrm{ml}$. EDTA was added to $\mathrm{I} \mathrm{mm}$ and mixed by shaking for $5 \mathrm{~min}$. The organisms were removed by centrifugation at $0^{\circ}$, and resuspended in cold distilled water with mixing for $5 \mathrm{~min}$. The organisms were removed by centrifugation and the supernatant fluid assayed for $\beta$-lactamase activity.

Bacterial extracts were prepared with a Branson Sonifer Model 75 using $2 \mathrm{~min}$. sonic disintegration at $0^{\circ}$ in $15 \mathrm{sec}$. bursts. R-factors were detected by the method of Watanabe (1964). Penicillinase activity was determined using a modification of Novick's (1962) iodometric assay with benzylpenicillin G as substrate.

\section{RESULTS}

Fourteen strains of Escherichia coli in which the $\beta$-lactamase was released by osmotic shock, and was thus a surface enzyme (Neu \& Chou, 1967), were all resistant to carbenicillin. Of 21 strains of $E$. coli in which the penicillinase was not released by osmotic shock 20 or $95 \%$ were sensitive to $25 \mu \mathrm{g} . / \mathrm{ml}$. or less of carbenicillin.

Escherichia coli strains which were sensitive to carbenicillin (Table I) were resistant to less than $125 \mu \mathrm{g}$. $/ \mathrm{ml}$. of ampicillin.

Table 2 is a comparison of the carbenicillin and ampicillin sensitivity of some Escherichia coli and Salmonella typhimurium strains in which the $\beta$-lactamase is either a surface or internally located enzyme. There do not appear to be significant differences in MIC levels of carbenicillin and ampicillin for either high level or low level penicillinase-producing strains. Strains of either organism in which the penicillinase is surface located showed high level resistance. When the penicillinase was an internal enzyme resistance did not exceed $250 \mu \mathrm{g}$. $/ \mathrm{ml}$. 
None of 15 Escherichia coli and I5 Salmonella typhimurium strains in which production of the $\beta$-lactamase is episomally mediated were sensitive to either ampicillin or carbenicillin. Several strains of $E$. coli has surface penicillinases but transfer of resistance to another strain was not possible.

Table I. Sensitivity of ampicillin resistant Escherichia coli to carbenicillin

\begin{tabular}{|c|c|c|c|}
\hline \multirow{2}{*}{$\begin{array}{c}\text { Ampicillin } \\
\text { resistance } \\
\mu \mathrm{g} . / \mathrm{ml} .\end{array}$} & \multicolumn{2}{|c|}{ Carbenicillin resistance } & \multirow{2}{*}{$\begin{array}{c}\text { Sensitive } \\
(\%)\end{array}$} \\
\hline & No. tested & No. sensitive* & \\
\hline $10-50$ & I8 & 16 & 90 \\
\hline $50-250$ & 21 & 19 & 90 \\
\hline$>250$ & 14 & 0 & 0 \\
\hline
\end{tabular}

Table 2. Comparison of carbenicillin-ampicillin sensitivity and location of penicillinase

$\begin{array}{cccc}\begin{array}{c}\text { Escherichia coli } \\ \text { strain }\end{array} & \begin{array}{c}\text { Penicillinase } \\ \text { location }\end{array} & \begin{array}{c}\text { Ampicillin } \\ \mu \mathrm{g} . / \mathrm{ml} .\end{array} & \begin{array}{c}\text { Carbenicillin } \\ \mu \mathrm{g} . / \mathrm{ml} .\end{array} \\ \text { DB 13 I } & \text { Surface } & >4000 & >4000 \\ \text { DB I30 } & \text { Internal } & 3 \cdot 2 & 3 \cdot 2 \\ \text { DB I I I } & \text { Internal } & 64 & 6 \cdot 4 \\ \text { DB 100 } & \text { Internal } & 250 & 100 \\ \text { DB I12 } & \text { Internal } & 8 & 4 \\ \text { FW/R I26 } & \text { Surface } & >2000 & >2000 \\ \text { DB I03 } & \text { Surface } & >2000 & >2000 \\ \text { Salmonella typhimurium } & & & \\ \text { BH 19 } & \text { Surface } & >8000 & >8000 \\ \text { BH 16 } & \text { Internal } & 16 & 32 \\ \text { A 100 } & \text { Surface } & 4000 & 4000\end{array}$

Table 3. Correlation of growth rates of two strains of Escherichia coli with the destruction of carbenicillin*

\begin{tabular}{|c|c|c|c|c|}
\hline \multirow[b]{2}{*}{$\begin{array}{l}\text { ime } \\
\text { hr) }\end{array}$} & \multicolumn{2}{|c|}{$\begin{array}{c}E \text {. coli DB 13I } \\
\text { (Surface penicillinase) }\end{array}$} & \multicolumn{2}{|c|}{$\begin{array}{c}\text { E. coli } \mathrm{DB} 307 \\
\text { (Internal penicillinase) }\end{array}$} \\
\hline & o.d. & $\begin{array}{c}\text { Carbenicillain } \\
\% \text { left }\end{array}$ & o.d. & $\begin{array}{c}\text { Carbenicillin } \\
\% \text { left }\end{array}$ \\
\hline 0 & 0.025 & 100 & 0.025 & 100 \\
\hline I & 0.130 & 75 & 0.085 & 85 \\
\hline 2 & 0.408 & 33 & 0.200 & 60 \\
\hline 3 & 0.748 & 5 & 0.451 & 50 \\
\hline 4 & $1 \cdot 020$ & 0 & 0.785 & 6 \\
\hline
\end{tabular}

* Overnight cultures were inoculated to $10^{4}$ cells $/ \mathrm{ml}$. After I hr at $35^{\circ}$ on a rotary shaker, $100 \mu \mathrm{g}$. per ml. carbenicillin was added. Growth was followed by turbidimetric change at $600 \mathrm{~m} \mu$. Carbenicillin was assayed (see 'Methods') on aliquots removed at noted times. DB I 3 I was resistant to $2000 \mu \mathrm{g}$. carbenicillin/ml. and DB 307 was resistant to $125 \mu \mathrm{g}$. carbenicillin $/ \mathrm{ml}$.

Variation in the size of the Escherichia coli inoculum from $10^{3}$ to $10^{7}$ organisms $/ \mathrm{ml}$. in the carbenicillin tube dilution did not lower the level of resistance of the high level resistant strains. Strains of $E$. coli resistant to less than $30 \mu \mathrm{g} . / \mathrm{ml}$. rarely showed an effect of inoculum size. Strains such as DB I08, in which the level of resistance was $63 \mu \mathrm{g} . / \mathrm{ml}$. at an inoculum of $10^{3}$ organisms, rose to $200 \mu \mathrm{g} / \mathrm{ml}$. with an inoculum of $10^{7}$ 
organisms. Highly resistant strains of E. coli. or Salmonella typhimurium in which the penicillinase was surface located probably destroyed the carbenicillin so rapidly that the effect of.inoculum size was not seen. Table 3 illustrates that the rapid growth rate of high level carbenicillin-resistant, surface penicillinase strains in the presence of carbenicillin, in contrast to those strains with lower resistance and an internal enzyme, is related to destruction of carbenicillin.

\section{Table 4. Test for synergy of carbenicillin and methicillin}

\begin{tabular}{|c|c|c|c|c|c|}
\hline \multirow[b]{2}{*}{ Strain } & \multirow{2}{*}{$\begin{array}{l}\text { Carbenicillin } \\
(\mu \mathrm{g} . / \mathrm{ml} .)\end{array}$} & \multirow{2}{*}{$\begin{array}{l}\text { Methicillin } \\
\text { ( } \mu \mathrm{g} . / \mathrm{ml} .)\end{array}$} & \multicolumn{3}{|c|}{$\begin{array}{c}\text { Carbenicillin }+ \text { Methicillir } \\
(\mu \mathrm{g} . / \mathrm{ml} .)\end{array}$} \\
\hline & & & 4 & + & 1000 \\
\hline $\begin{array}{l}\text { Pseudomonas a. } 2 \\
\text { Escherichia coli } 132\end{array}$ & $\begin{array}{r}250 \\
6\end{array}$ & $\begin{array}{r}1000 \\
500\end{array}$ & $\begin{array}{l}4 \\
2\end{array}$ & $\begin{array}{l}+ \\
+\end{array}$ & $\begin{array}{r}1000 \\
500\end{array}$ \\
\hline E. coli 18 & 4 & 500 & 0.5 & + & 500 \\
\hline Enterobacter 10 & 64 & 1000 & 4 & + & 500 \\
\hline Klebsiella 273 & 250 & 1000 & 32 & + & 1000 \\
\hline Klebsiella 272 & 125 & 500 & 32 & + & 100 \\
\hline E. coli 13I & 4000 & $>4000$ & 4000 & + & $>4000$ \\
\hline S. typhimurium A 100 & 1000 & 2000 & 1000 & + & 1000 \\
\hline Pseudomonas a. IOI & 8000 & 16000 & 4000 & + & 8000 \\
\hline Proteus $m$. & 4000 & $>4000$ & 4000 & + & 4000 \\
\hline
\end{tabular}

Since carbenicillin is hydrolyzed by $\beta$-lactamases of most Enterobacteriaceae we attempted to lower the level of resistance of various organisms by performing the tube dilution in the presence of a penicillinase-resistant penicillin such as methicillin. Using a checkerboard method of broth dilution it is possible to determine whether combinations of antibiotics are synergistic, antagonistic or additive in effect. Using either methicillin or dicloxacillin, only I strain of 32 tested showed synergy. Eleven Pseudomonas aeruginosa, 8 Escherichia coli, 4 Enterobacter, 7 Klebsiella and 2 Proteus were tested. Table 4 demonstrates that only klebsiella 272 showed true synergy. In the few cases where the MIC of carbenicillin was lowered the MIC of methicillin in the combination was equal to the MIC of methicillin alone. Fifty per cent of these strains showed a synergistic effect of ampicillin and methicillin.

\section{DISCUSSION}

Carbenicillin, which is hydrolyzed by $\beta$-lactamases of both Gram-positive and Gram-negative bacteria, had been thought to be active against some ampicillinresistant Escherichia coli. These investigations show that $E$. coli which possess surface penicillinases are resistant to carbenicillin. Not all of these strains with surface penicillinases could transfer resistance to ampicillin and carbenicillin to another strain of $E$. coli. In all of these episome strains the penicillinase was a surface enzyme. Carbenicillin is effective only against ampicillin-resistant $E$. coli in which resistance is at a low level.

It is not readily apparent why carbenicillin shows less synergist action than ampicillin when used with penicillinase-resistant penicillins such as methicillin. It is possible that the entry into the cell of carbenicillin is more rapid or that its affinity for $\beta$ lactamases is greater than that of ampicillin. There is no practical value to combinations of carbenicillin with other penicillins since concentrations from 3000 to 20,000 $\mu \mathrm{g} . / \mathrm{ml}$. can be obtained in urine (Neu \& Swarz, 1969). 
Although carbenicillin is unlike ampicillin in that it is active against pseudomonas strains, its activity against members of the Enterobacteriaceae is similar to ampicillin, particularly in regard to $\beta$-lactamase producing strains.

\section{REFERENCES}

ACred, P., Brown, D. M., Knudsen, E. T., Robinson, G. N., \& Sutherland, R. (I967). New sem synthetic penicillin active against Pseudomonas pyocyanea. Nature, Lond. 215, 25.

BODEY, G. P. \& TERRELL, L. M. (I968). In-vitro activity of carbenicillin against gram-negative bacilli. J. Bact. 95, 1587.

Brumfitt, W., Percival, A., \& Leigh, D. A. (1967). Clinical and laboratory studies with carbenicillin, a new penicillin active against Pseudomonas pyocyanea. Lancet 1,1289 .

NeU, H. C. (1968). The surface localization of penicillinases in Escherichia coli and Salmonella typhimurium. Biochem. Biophys. Res. Commun. 32, 258.

NeU, H. C. \& Chou, J. (1967). Release of surface enzymes in Enterobacteriaceae by osmotic shock J. Bact. 94, I934.

Neu, H. C. \& SwaRz, H. (1969). Carbenicillin: use in serious infections caused by Pseudomonas. Clin. Res. $\mathbf{1 7}, 372$.

Novick, R. P. (I962). Micro-iodometric assay of penicillinase. Biochem. J. 83, 236.

Sutherland, R. \& BATCHELOR, F. R. (1964). Synergistic activity of penicillins against penicillinase from gram-positive and gram-negative bacteria by substrate analogues. Nature, Lond. $201,868$.

Watanabe, T. (1964). Selected methods of genetic study of episome mediated drug resistance in bacteria. Meth med. Res. ro, 202. 